\title{
POLYOMAVIRUS NEPHROPATHY: RISK ANALYSIS IN PAIRED RENAL TRANSPLANT RECIPIENTS
}

\author{
Nefropatia por poliomavírus: fatores de risco em transplante renal pareado
}

\author{
André Barros Albuquerque Esteves', Luiz Roberto Sousa Ulisses', Leonardo Figueiredo Camargo ${ }^{1,2}$, Gabriel Giollo Rivelli,2, \\ Marcos Vinicius de Sousa ${ }^{1,2}$, Marilda Mazzali',2
}

Funding: no funding

Authors have no conflict of interest to declare.

\begin{abstract}
Polyomavirus allograft nephropathy (PVAN) has a negative impact on allograft function and survival. Analysis of paired kidneys from same donor can help to understand the role of recipient risk factors for PVAN. This analysis can also define donor related risk factors. Purpose: To identify recipient related risk factors for PVAN. Patients and Methods: Transversal cohort of 24 renal transplant patients in regular outpatient clinic follow up. Twelve patients with PVAN and their paired controls (recipients from same donor) without decoy cells in cytology were included in this analysis. Medical records were analyzed for demographic data, information of transplant and post-transplant data (acute rejection, renal function, immunosuppression). Results: Groups were comparable for initial immunosuppressive therapy based on basiliximab induction, tacrolimus, mycophenolate and steroids. Etiology of end-stage renal disease, race, age, HLA matching and delayed graft function considered as risk factors were also similar between patients with or without PVAN. However, PVAN group had more male patients (91.6 vs. $66.6 \%$, PVAN versus control, $p<0.05)$, higher incidence of biopsy proven acute rejection $(41.6 \%$ vs. $8.3 \%$, PVAN vs. control, $p<0.05)$ and a trend to shorter cold ischemia time $(15.6 \pm 6.2$ versus $19.7 \pm 5.0, p=0.06)$. Conclusion: In this series, there were no significant differences in immunosuppressive therapy, age and HLA matching between patients with or without PVAN common risk factors. The only factors to be considered in this series were older age and a trend to shorter cold ischemia time in PVAN patients.
\end{abstract}

Keywords: Polyomavirus, Polyomavirus Infections, Kidney Transplantation.

Institution:

1 Renal Transplant Unit- Division of Nephrology- School of Medical Sciences, University of Campinas, Campinas/SP - Brazil

2 Laboratory of Transplant Investigation (LInT)- School of Medical Sciences, University of Campinas, Campinas/SP - Brazil.

\section{Correspondence:}

Marilda Mazzali, MD

Division of Nephrology, Department of Medicine

School of Medical Sciences, State University of Campinas- DCM/

FCM/UNICAMP

Rua Tessalia Vieira de Camargo, 126 - Cidade Universitaria Zeferino

Vaz - CEP 13083-970 - Campinas/SP - Brazil

Phone: 55-19-35218204

Fax: 55-19-3521-8208

Email: marildamazzali@gmail.com

Received: 13/06/2016

Accepted: 02/07/2016

\section{INTRODUCTION}

Polyomavirus allograft nephropathy (PVAN) has a negative impact on graft function and survival. ${ }^{1}$ Despite its low incidence (1 to $10 \%$ ), graft loss can occur in more than $50 \%$ of patients, usually associated with histological pattern B or $\mathrm{C}^{2}{ }^{2}$ Risk factors for PVAN remains controversial. Studies suggest that older age; male gender, Caucasian and recipients from deceased donors are at increased risk..$^{1-3}$ The immunosuppressive therapy also can be implicated in the pathophysiology of PVAN. Presence of more potent immunosuppressive protocols, usually for $A B O$ incompatible, low HLA match transplants, high anti HLA antibody titles, and therapy with tacrolimus and mycophenolate are considered as 
André Barros Albuquerque Esteves, Luiz Roberto Sousa Ulisses, Leonardo Figueiredo Camargo, Gabriel Giollo Rivelli, Marcos Vinicius de Sousa, Marilda Mazzali

risk factors. ${ }^{4}$ Other proposed risk factors includes the presence of diabetes, prolonged cold ischemia time, delayed graft function, previous CMV infection. However, while the majority of studies consider only recipient related risk factors, others consider that Polyomavirus infection comes with the kidney, and development of PVAN was a consequence of an inadequate immune response of recipient to an infected kidney. ${ }^{5,6}$ These groups consider that donor positive BKV serology will be a risk factor to consider. In order to identify the source of PVAN, from recipient or donor, we hypothetized that the analysis of a pair of kidneys from the same donor, one with PVAN and the other without PVAN could define the source of PVAN.

\section{PATIENTS AND METHODS}

Retrospective analysis of Transplant Unit database, including renal transplants from July 2003 to January 2013. Patients included in local screening protocol for Polyomavirus and recipients from a deceased donor were considered as suitable for analysis. Protocol was approved by local Ethics Committee.

Local screening protocol includes collection of urine samples at months $1,3,6,9$ and 12 after transplant, and every 3 months during the first 3 years after transplant. Urine samples are centrifuged and stained with Papanicolaou staining, as previously described 7,8 Presence of at least one epithelial cell with viral inclusion was considered as positive cytology, and another urine sample was collected within a shorter interval. In presence of positive cytology tacrolimus dose was reduced to obtain a through level $\leq 6 \mathrm{ng} / \mathrm{dl}$ and ciprofloxacin $250 \mathrm{mg} P O$ was started. In presence of 3 samples positive for decoy cells, a renal biopsy was performed, searching for tubular cell viral inclusions, positive for SV40 staining. [Figure 1]

From database, we identified 711 renal transplant recipients from deceased donors with sequential urine cytology screening. We selected patients with a confirmed diagnosis of PVAN by biopsy, older than 18 years old at transplant, recipients from a deceased donor and with a paired kidney transplanted at the same Unit and followed for more than 6 months. Initial research resulted in 16 patients. However, 4 were excluded as both recipients developed PVAN during follow up. The study group compared 12 pairs of transplants.

Data collected from medical records included demographic data (etiology of end stage renal disease, gender, race, age, length of pre transplant dialysis therapy), transplant information (cold ischemia time, immunosuppressive therapy, delayed graft function, acute rejection), and follow up information (time to PVAN diagnosis, renal function, urine protein/creatinine ratio). End points were graft loss or patient loss.

Statistical analysis: data was presented as mean \pm standard deviation. Groups were compared by Student $t$ test or chi square, and significance considered if $p<0.05$.

\section{RESULTS}

PVAN patients and controls were comparable for age $(45.2 \pm 11.3$ vs. $49.1 \pm 10.2$ years old, PVAN vs. control, $\mathrm{p}=\mathrm{ns})$, race $(66.6 \%$ Caucasian in both groups) and primary renal disease. Gender analysis showed a majority of male in PVAN group (91.6\% vs.66.6\% PVAN vs. control, $p<0.001)$. Immunosuppressive therapy was comparable between groups. All patients received Basiliximab as induction therapy, and were maintained with steroids, mycophenolate and tacrolimus until the diagnosis. Tacrolimus through level, considered a risk factor, was comparable between groups $(9.1 \pm 3.9$ vs. 7.1 $\pm 3.8 \mathrm{ng} / \mathrm{dL}$, PVAN vs. control, $\mathrm{p}=\mathrm{ns}$ ).

Groups were also similar in HLA matching, in both $A B$ $(1.1 \pm 0.7$ vs. $1.1 \pm 0.7, p=n s)$ and $D R(1.7 \pm 0.5$ vs. 1.6 \pm 0.7 , PVAN vs. control, $p=n s)$ loci. Despite a trend to lower cold ischemia time in PVAN group (15.6 \pm 6.2 vs. $19.7 \pm 5.0$ hour, PVAN vs. control, $p=0.08$ ), the incidence of delayed graft function (50 vs. $58.3 \%, p=n s$ ) and CMV infection ( $8.3 \%$ vs. $16.6 \%$, PVAN vs. control, $p=n s)$. Biopsy- proven acute rejection was more frequent in PVAN group ( $41.6 \%$ vs. $8.3 \%$, PVAN vs. control, $p<0,05)$, diagnosed before PVAN. After a 5-year follow up, graft loss was higher in PVAN group (58.3 vs. $25 \%$, PVAN vs. control, $p<0.05)$.

\section{DISCUSSION}

Despite well characterized for incidence and impact on graft function and graft loss, Polyomavirus allograft nephropathy remains as a challenge for physicians to identify patients on risk and to define the best therapeutic approach. ${ }^{1}$

Risk factors can be related to recipient, donor or to viral ability to move from latent to lytic phase. Different studies suggested that immunosuppressive status was associated with a higher risk for PVAN, including $A B O$ incompatible transplants, high immunological risk (high PRA or low HLA matching) and use of high doses of tacrolimus and mycophenolate. ${ }^{1,2,4}$ Studies also 
Figure 1: Screening protocol for Polyomavirus infection in renal transplant recipients.

\section{Screening protocol}

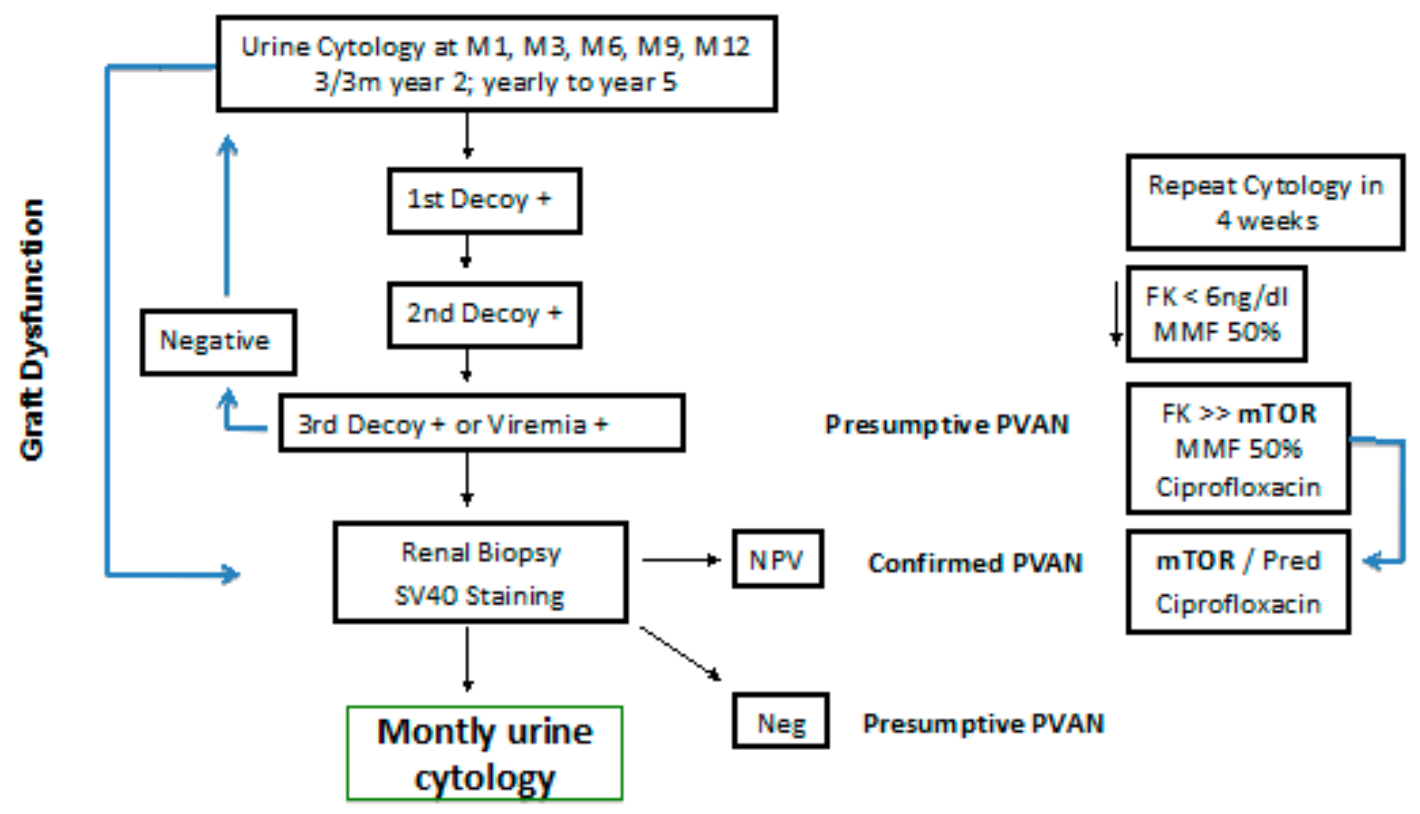

considered the risk of transmission of Polyomavirus from the infected kidney. Bohl et al suggested that recipients of a kidney from a seropositive donor had an increased risk for PVAN. ${ }^{6}$ In order to identify risk factors from the recipient, we decided to analyze paired transplant recipients from a same donor, where one recipient developed PVAN and the other remained with negative urine cytology during a 5 year follow up.

We analyzed risk factors previously described, such as age, gender, HLA matching, induction therapy and immunosuppressive therapy dosage. From analyzed data, only male gender and increased incidence of acute rejection episodes were considered as risk factors in this series. We have to consider that this group is a low immunological risk group. However, despite the higher incidence of acute rejection in PVAN group, we didn't observe differences in tacrolimus or mycophenolate doses or trough levels, classically considered as risk factors. ${ }^{9,10}$
Limitations of this study are the retrospective, single center design. Also, screening included only urine cytology, with a low positive predictive value, but with almost $100 \%$ of negative predictive value. There are few reports in literature comparing both kidneys from the same donor, followed by the same transplant center with a regular screening protocol. A longer follow up and an increase in the sample could straighten the results and conclusions. Also, screening of BK viremia using PCR could be a useful tool in future studies.

\section{CONCLUSION}

In this series, PVAN was associated with male gender, acute rejection episodes and a trend to short cold ischemia time. Immunosuppressive therapy was not identified as a risk factor in this study. PVAN was associated with worse graft survival in a 5-year follow up. 
André Barros Albuquerque Esteves, Luiz Roberto Sousa Ulisses, Leonardo Figueiredo Camargo, Gabriel Giollo Rivelli, Marcos Vinicius de Sousa, Marilda Mazzali

\section{RESUMO}

Nefropatia pelo Poliomavírus (PVAN) tem impacto negativo na sobrevida e função do enxerto renal. Análise de pares de rins de um mesmo doador pode auxiliar o entendimento dos fatores de risco relacionados, tanto ao receptor como ao doador, para ocorrência de PVAN. Objetivo: Identificar fatores de risco para PVAN associados ao receptor. Métodos: Estudo de corte transversal, avaliando 24 receptores de transplante renal em acompanhamento ambulatorial regular. Doze pacientes com PVAN e seus controles pareados (receptores do rim contralateral do mesmo doador), com citologia urinária negativa foram incluídos. Dados demográficos e informações do transplante e do período pós-transplante (rejeição aguda, função renal e imunossupressão) foram coletados a partir de prontuários médicos. Resultados: Os grupos foram comparáveis para imunossupressão inicial, que incluía indução com basiliximab, tacrolimo, micofenolato e corticoide. Etiologia da doença renal crônica, raça, idade, compatibilidade HLA e incidência de retardo de função renal, considerados fatores de risco, foram semelhantes entre pacientes com ou sem PVAN. Entretanto, no grupo PVAN predominavam pacientes do sexo masculino (91,6 vs. 66,6\%, PVAN vs. Controle, $p<0,05)$; maior incidência de rejeição aguda comprovada por biópsia $(41,3$ vs. $8,3 \%$, PVAN vs. Controle, $p<0,05)$ e tendência a menor tempo de isquemia fria $(15,6 \pm 6,2$ vs. 19,7 $\pm 5,0, p=0,06)$. Conclusão: Na presente série, não houve diferença significativa em imunossupressão, idade e compatibilidade HLA, considerados fatores de risco, entre os pacientes com ou sem PVAN. Os únicos fatores de risco nesta série foram idade maior e tendência à isquemia fria mais curta nos pacientes com PVAN.

Descritores: Polyomavírus; Infecções por Polyomavírus; Transplante Renal.

\section{REFERENCES}

1. Dall A, Hariharan S. BK virus nephritis after renal transplantation. Clin J Am Soc Nephrol 2008;3:S68-75.

2. Ramos E, Drachemberg CB, Wali R, Hirsch HH. The decade of Polyomavirus BK-associated nephropathy: State of affairs. Transplantation 2009;87:621-30.

3. Rahamimov R, Lustig S, Tovar A, Yussim A, BarNatham N, Shaharabani E et al. BK Polyoma virus nephropathy in kidney transplant recipient: the role of new immunosuppressive agents. Transpl Proc 2003;35:604-5.

4. Rocha PN, Plumb TJ, Miller SE, Howell DN, Smith SR. Risk factors for BK Polyomavirus nephritis in renal allograft recipients. Clin Transplant 2004;18:456-62.

5. Comoli P, Binggeli S, Ginevri F, Hirsch HH. Polyomavirus associated nephropathy: update on BKvirus specific immunity. Transplant Infect Dis 2006;8:86-94.

6. Bohl DL, Storch GA, Ryschkewitsch C, Gauldreault-Keener M, Schnitzler MA, Major EO et al. Donor origin of BK virus in renal transplantation and role of HLA c7in susceptibility to sustained BK viremia. Am J Transplant 2005;5:2213-21.
7. Santos RL, Manfrinatto JA, Cia EM, Carvalho RB, Quadros KR, Alves-Filho G, Mazzali M. Urine cytology as a screening method for Polyomavirus active infection. Transplant Proceed 2004; 36(4):899-901.

8. Kroth LV, Henkin CS, Peres LD, Paganella MC, Mazzali M, Duval VD et al. Prevalence of urinary decoy cells and associated factors in Brazilian kidney, pancreas and kidney-pancreas transplantation. Transplant Proceed 2012; 44(8): 2394-6.

9. Pai D, Mann DM, Malik A, Hoover DR, Fyfe B, Mann RA. Risk factors for the development of BK virus nephropathy in renal transplant recipients. Transplant Proceed 2015; 47(8);2465-9.

10. Gonzalez S, Escobar-Serna DP, Suarez O, Benavides X, Escobar-Serna JF, Lozano E. BK virus nephropathy in kidney transplantation: an approach proposal and update on risk factors, diagnosis and treatment. Transplant Proceed 2015; 47(6): 1777-85. 